DOI: 10.22559/folklor.972

Folklor/edebiyat, cilt:25, say1: 97-1, 2019/1

\title{
Göçle Gelen Yabancı Uyruklu Öğrencilerin Okul Ortamında Karşılaştıkları Sorunlar
}

\section{The Problems of Immigrant Foreign Students in School Environment}

\begin{abstract}
Aygil Takır*
Ayşen Özerem**

$\ddot{O} \mathbf{z}$

Bu araştırmanın amacı, Kuzey Kıbrıs Türk Cumhuriyeti’nde bulunan bir devlet kolejinde öğrenim gören yabancı uyruklu öğrencilerin, okul ortamında yaşadıkları sorunları rehber öğretmen ve okul idarecileri gözünden ortaya koymak ve çözüm önerileri geliştirmektir. Göç etmiş yabancı uyruklu öğrencilerin uyum sürecinde en büyük sorumluluk sahibi olarak rehber öğretmenler ve okul idarecileri görülmektedir. $\mathrm{Bu}$ sebeple, rehber öğretmenlerin ve müdür yardımcılarının yabancı uyruklu öğrencilerin yaşadıkları problemlerle ilgili verecekleri bilgiler ile tespit edilen sorunlara yönelik olarak hem bireylere hem de okul işleyişine katkı sağlanacağı düşünülmektedir. Araştırmanın çalışma grubu, 2017-2018 eğitim-öğretim yılında KKTC'de bir devlet kolejinde görev yapan 3 rehber öğretmen ve 6 müdür yardımcısıdır. Araştırma, nitel araştırma yöntemlerinden durum çalışması olarak tasarlanmıştır. Araştırmada veriler, araştırmacılar tarafından geliştirilen açık uçlu sorulardan oluşan yarı yapılandırılmış görüşme formu ile toplanmıştır. Veri analizini gerçekleştirmek için betimsel ve içerik analizinden yararlanılmıştır. Araştırma sonucunda, rehber öğretmenlerin ve müdür yardımcılarının eğitim-öğretim sürecinde yabancı uyruklu öğrencilerle ilgili bazı sorunlar gözlemledikleri tespit edilmiştir. Bu sorunların en başında dil, kültür farklılığ , dersle ilgilenmeme/öğretimden kopma ve uyum problemlerinin geldiği görülmektedir.
\end{abstract}

Anahtar sözcükler: Yabancı Uyruklu Öğrenciler, Göçle Gelen Yabancı Uyruklu Öğrenciler, Okul Sorunlarl, Göçle Gelen Sorunlar.

\begin{abstract}
The purpose of this research is to detect the problems experienced by foreign students studying in a state college in the Turkish Republic of Northern Cyprus with the point of view of the guidance teachers and school administrators and to develop the solutions. Guidance teachers and school administrators are seen as having the greatest responsibility in the integration process of immigrated foreign students. For this reason, it is considered that the guidance teachers and assistant principals will contribute to the functioning of both the individuals and the schools in order to solve the problems determined by the
\end{abstract}

\footnotetext{
* Dr., Doğu Akdeniz Üniversitesi, Eğitim Fakültesi, Matematik ve Fen Bl. Eğitimi Bl. aygil.takir@emu.edu.tr

** Dr., Milli Eğitim Bakanlığı, Lefkoşa Maarif Koleji, aysenozerem@ @ahoo.com
} 
collected information about the problems experienced by foreign students. The sample of the research is 3 guidance counselors and 6 assistant principals who work in state college in the TRNC, in the academic year 2017-2018. The research was designed as a case study from qualitative research methods. In the study, data were collected by semi-structured interview form consisting of open-ended questions developed by the researchers. Descriptive and content analyses was used to perform data analysis. As a result of the research, it was determined that the guidance teachers and assistant principals observed some problems related with foreign students. The major of these problems are language, culture difference, lack of interest in teaching/learning process, and adaptation problems.

Keywords: Foreign Students, Immigrant Foreign Students, School Problems, Immigration.

Giriş

Göç kavramı insanlık tarihi kadar eski olmakla birlikte toplumun sosyal, kültürel, siyasi ve ekonomik tüm dinamiklerini etkileyen bir süreçtir. Bu nedenle, göç olgusu insanların sadece fiziki yer değiştirmeleri olarak ele alınamayacak kadar önemli ve geniş bir kavramdır. Göç, çeşitli kaynaklarda, bireylerin bir takım sebeplere bağlı olarak bireysel ya da ailece, kendi istekleri veya zorlama ile geriye dönüş veya sürekli yerleşim ile sonuçlanabilen coğrafik, toplumsal ve kültürel bir yer değiştirme hareketidir (Koçak ve Terzi, 2012; Sarıkaya, 2014; Topsakal, 2013). O halde, göç, bireysel ya da bir sosyal grubun mekân değisşikliği şeklinde; yakın ya da uzak bir yere ve geçici ya da geri dönmemek üzere gerçekleşebilir. Göç olayının temelinde bulunan en temel faktör ise bireylerin ekonomik açıdan geçimlerini sağlamak için daha elverişli yerlere gitmeleri ve buradaki imkânlardan faydalanmak suretiyle yeni bir yere yerleşmektir (Atalay, 1994).

Göç, oluşmasında rol oynayan nüfus hareketini sağlayan faktörler açısından ele alındığında, serbest göç ve güdümlü mecburi göç olarak iki kategoride toplanır. Serbest göç, fertlerin daha iyi hayat şartları, iş imkânları, mali olanakları, güvenlik, istikrar ve çeşitli sosyal imkânlar elde edebilmek arzusu ile serbestçe yer değiştirmeleridir. Güdümlü mecburi göç ise devletlerin çeşitli sosyal, ekonomik ve güvenlik gibi konularda aldıkları kararların uygulanması sonucunda veya bir yerdeki bireyler/gruplar arasındaki çatışmaların yarattıkları sorunlar sebebiyle ortaya çıkan göç hareketleridir (Akkayan, 1979). Bir diğer göç sınıflandırması ise iç göç ve $d \imath$ ş göç olarak nüfus hareketlerinin yöneldiği coğrafi alanlar itibariyle yapılan sınıflandırmadır. İç göç, bir ülkenin milli sınırları içinde yer alan alanlara yapılırken iken dış göç ülkenin milli sınırların dişında yer alan göç olarak tanımlanmaktadır.

İnsanların göç etmesinin temelinde genel olarak ekonomik problemler, yaşam-çevre şartlarındaki değişmeler, eğitim hizmetlerindeki yetersizlikler, siyasi problemler ve savaşlar olarak görülmektedir (Kaştan, 2015). Göçe dair bu nedenler göç ile ilgili araştırmaların farklı disiplinlerde yer almasına sebep olmuş ve bu yönüyle göç, antropologların, sosyal bilimcilerin, 
eğitim bilimcilerin, psikologların ve psikolojik danışmanların ilgisini çeken ve incelemelerine konu olan bir kavram olmuştur (Şahin, 1999). Göçlerin sonuçlarına baktığımızda ise kendi kültürden ayrılma ve yeni bir dil, kültür ve ortamla karşılaşma olduğu için bazı sorunları da beraberinde getirdiği aşikârdır (Özdemir, Benzer, Akbaş, 2009; Kılıç, 2014; Uluocak, 2009).

Araştırmanın konusuna paralel olarak, özelde göçün çocuklar ve ergenler üzerindeki etkilerine bakıldığında, göç yaşayan bireylerde birçok sorun ortaya çıktığı, özellikle, bir takım psikolojik sorunlar, depresif bozukluklar ve uyum sorunları gibi, sık görüldügü belirlenmiştir. Pek çok araştırma ile göç öncesi yaşam yeri ile yeni yerin, sosyal ve kültürel farklılığının bu sorunları arttırdığı saptanmıştır (Hastürk, 2007). Göç eden ergenlerde gözlenen davranış bozuklukları, düşük benlik algısı, kişilik çatışması ve ebeveynlerle yaşanan problemlerin (Moilonen, 1998) her ne kadar tüm ergenler için bilinen gelişimsel kritik süreçler olsa da, göç deneyimleri ve kültürel değişme ile daha da şiddetlendiği yapılan çalışmalar ile ortaya konulmaktadır (Gün, 2002). Göç etmiş ergenler göçle beraber, kendilerini yeni ye eski kültürleri bir arasında seçim yapmak zorunda oldukları bir pozisyonda bulmaktalar ve bu zor seçimler, ergenlerde davranış problemlerinin gelişmesine neden olmaktadır. Göç eden ergenlerin uyumlarıyla ilgili, dil güçlükleri ve okul başarısızlığı iki önemli faktör olarak öne çıkmakta (Sam, 1991) bunun yanında davranış bozukluğu, benlik çatışması, benlik algısında düşüklük gibi problemler de görülmektedir (Berry ve Sam, 1995).

$\mathrm{Bu}$ süreçte eğitim kurumlarına göç etmiş bireylerin göç edilen topluma uyumlarını gerçekleştirme bakımından önemli görevler düşmektedir. Göç sonrası dönemde uyum sağlamayı kolaylaştırıcı bir kurum olarak okulların böyle bir işleve sahip olduğu düşünülmektedir. Okul, göç ile gelinen çevreye kolay ve başarılı bir uyum gerçekleştirmek için ortam ve hizmet sunmalıdır. Göç sonucu yapılan okul değişikliği, çocuk için aynı zamanda çevre değişimini de içermekte ve uyum açısından kritik öneme sahip olmaktadır. Göç yaşayan çocukların en önemli sorunlarının başında okul değişikliği gelse de, okulda uyumu gerçekleşen çocuklar için göçün olumsuz etkilerinin azalacağı aşikârdır.

KKTC ve Göç

Göç olgusu, sosyal bir hareket olmakla birlikte ekonomik yaşamdan kültüre kadar bireyin tüm yaşamını etkileyen önemli bir değişim aracıdır. KKTC belirli dönemlerde Türkiye Cumhuriyeti ve Bulgaristan'dan toplu göç almıştır (Çiçek, 2017). Bununla birlikte, günümüzde toplu göçler yerine bireysel göçler devam etmektedir. Yeni iş ve yaşam olanakları için yapılan göçler, ağırlıklı olarak Türkiye, İngiltere, Rusya, Pakistan, Bangladeş, Avusturalya, Afganistan, Kırgızistan, Kazakistan, Tacikistan, Suriye, Ürdün, İran ve Irak gibi ülkelerin vatandaşları tarafından gerçekleşmektedir (Atasoy, 2011; Keser, 2006). KKTC Milli Eğitim ve Kültür 
Bakanlığı'nın son beş yıllık eğitim istatistiklerine bakıldığında, giderek artan oranda yabancı uyruklu öğrencinin, KKTC resmi ve özel eğitim kurumlarına kayıt yaptırdığı görülmektedir. KKTC Milli Eğitim ve Kültür Bakanlığı istatistikleri incelendiğinde, vatandaşlıkların KKTC, TC, KKTC-TC ve 3. Ülke vatandaşlıkları olarak gruplandığı görülmektedir. KKTC Milli Eğitim ve Kültür Bakanlığı, 2017-2018 Eğitim İstatistikleri Yıllığı'na göre ortaokul ve lise öğrencileri toplamı 23.728 olup, 14.212 KKTC, 5.940 TC, 2.260 KKTC-TC ve 1.316'sı 3. ülke uyrukludur. KKTC'nin bulunduğu coğrafyadan ötürü göçlerin artması olası görünmekte ve eğitim alanında da diğer alanlarda olduğu gibi bir takım önlemlerin alınması gerekli görülmektedir. Araştırmada kullanılan yabancı uyruklu öğrenci ifadesi ile 3. ülkelerden öğrenim görmek için bir başka ülkeye giden, mülteci, sığınmacı ve uluslararası koruma ihtiyacı olan kişiler ele alınmaktadır (Çağlar, 1997).

\section{Araştırmanın amacı ve önemi}

KKTC'ye yönelik olarak sürdürülen göç sonucunda ortaya çıkan çok kültürlülük her alanda olduğu gibi eğitim-öğretim ortamları da etkilemektedir. Bu araştırmanın amacı, Kuzey Kıbrıs Türk Cumhuriyeti'nde bulunan bir devlet kolejinde öğrenim gören yabancı uyruklu öğrencilerin, okul ortamında yaşadıkları sorunları rehber öğretmen ve okul müdür yardımcıları gözünden ortaya koymak ve çözüm önerileri geliştirmektir. Yabancı uyruklu öğrenciler, öğretmenleri ve velileri ile farklı bir çalışmanın dâhilinde (Özerem ve Takır, 2018) yapılan bazı görüşmelerde, öğrencilerin problem yaşadıklarında genellikle rehber öğretmenlere ve müdür yardımcılarına yönlendirildikleri ve uyum süreçlerinin genellikle rehber öğretmen tarafından takip edildiği belirtilmiştir. Disiplinle ilgili süreçler ise müdür yardımcıları tarafından takip edilmektedir. Dolayısı ile göç etmiş yabancı uyruklu öğrencilerin uyum sürecinde en büyük sorumluluk sahibi olarak rehber öğretmenler görülebilir. Bu sebeple, rehber öğretmenlerin yabancı uyruklu öğrencilerin yaşadıkları problemlerle ilgili verecekleri bilgiler ile tespit edilen sorunlara yönelik olarak hem bireylere hem de okul işleyişine katkı sağlanacağı düşünülmektedir. Benzer gerekçe ile okul işleyişinden sorumlu olan müdür yardımcılarının gözünden yabancı uyruklu öğrencilerin yaşadıkları sorunların belirlenmesi ve çözüm önerileri geliştirilmesi önemli görülmektedir. Ana unsurun insan olması nedeniyle, eğitim kurumlarında sorunların yaşanması doğaldır. Eğitim ortamlarında görülen bu sorunların tamamen ortadan kaldırılması ise mümkün değildir. Eğitim kurumlarında, sorunların sebeplerini tespit ederek, sorunlara yönelik eğitsel önlemler alınması büyük önem taşımaktadır. Bu sebeple, eğitim kurumlarında görevli olan herkesin sorunların çözümünde işbirliği içerisinde hareket edebilmesi önemlidir. Bu sebeple; yapılan bu çalışmada okullarda özellikle öğrencileri tanıma ve takipten sorumlu olan rehber öğretmenler ve müdür yardımcılarının göçle gelen yabancı 
uyruklu öğrencilerde belirledikleri sorunlar, bu sorunlar için geliştirdikleri çözümler ve önerileri araştırmak önemli görülmektedir. KKTC'ne bulunduğu coğrafyanın şartlarından dolayı üçüncü dünya ülkelerinden (Pakistan, Bangladeş, İngiltere, Avustralya, Afganistan, Kırgızistan, Kazakistan, Tacikistan, Suriye, Ürdün, İran ve Irak vb.) göçler devam etmektedir. Bu sebeple, araştırma sonuçlarının Milli Eğitim Bakanlığı tarafından değerlendirilerek, göçle gelmiş yabancı uyruklu öğrenciler için yapılacak çalışmaların ve alınacak önlemlerin belirlenmesinde katkı sağlayıcı olacaktır.

Araştırmada, temel amaç doğrultusunda şu araştırma sorularına yanıt aranmıştır:

1. Rehber öğretmen ve müdür yardımcılarına göre KKTC devlet kolejlerinde öğrenim gören yabancı uyruklu öğrencilerin okul ortamında yaşadıkları sorunlar nelerdir?

2. Yaşanılan sorunların çözümüne yönelik yapılan çalışmalar nelerdir?

3. Yaşanılan sorunların çözümüne yönelik çözüm önerileri nelerdir?

Araştırma, 2017-2018 eğitim-öğretim yılında, KKTC Milli Eğitim ve Kültür Bakanlığı'na bağlı, resmi bir devlet kolejinde görev yapan rehber öğretmenler ile müdür yardımcıları ve verdikleri cevaplar ile sınırlıdır.

\section{Yöntem}

\section{Model}

Bu araştırmada ayrıntılı ve derinlemesine veri toplama, katılımcıların bireysel algılarını, deneyimlerini ve bakış açılarını doğrudan öğrenme, mevcut durumları anlama ve açıklama amacıyla nitel araştırma yaklaşımı kullanılmıştır (Büyüköztürk,ve diğ. 2009). Nitel araştırma desenlerinden durum çalışmasına yer verilmiştir. Durumlar, bir birey, bir kurum, bir grup, bir ortam çalışacak durumlara örnek oluşturabilir (Yıldırım ve Şimşek 2008). Bu çalışmada Kuzey Kıbrıs Türk Cumhuriyeti’ndeki Milli Eğitim ve Kültür Bakanlığı’na bağlı bir devlet koleji nitel durum çalışmasında temel alınarak bu okullarda görev yapan rehber öğretmenler ve müdür yardımcıları araştırma kapsamındadır.

Araştırmada, nitel veri toplama araçlarından biri olan görüşme yöntemi (Karataş, 2015) kullanılmıştır. Görüşme, katılımcıların duygu, deneyim ve tutumlarını ortaya koymayı amaçlayan ve bunları onların düşüncelerini saptayarak gerçekleştiren bir veri toplama tekniğidir (Ekiz, 2009). Araştırmada, katılımcı rehber öğretmenlerin ve müdür yardımcılarının görüşme sorularına içtenlikle cevap verdikleri varsayılmıştır.

\section{Çalışma Grubu}

Araştırmanın çalışma grubu, 2017-2018 eğitim-öğretim yılında KKTC'de bir devlet kolejinde görev yapan 3 rehber öğretmen ve 6 müdür yardımcısıdır. Çalışma tamamen 
gönüllülük esasına göre yürütülmüştür. Araştırmaya katılmayı kabul eden rehber öğretmenler ve müdür yardımcıları ile ilgili bilgiler Tablo 1'de sunulmuştur.

Tablo 1. Araştırmaya katılan rehber ögretmenler ve müdür yardımcıları ile ilgili demografik bilgiler.

\begin{tabular}{|c|c|c|c|c|}
\hline $\begin{array}{l}\text { Kat1lımc1 } \\
\text { Kodu }\end{array}$ & Cinsiyet & Branş & Eğitim Düzeyi & $\begin{array}{c}\text { Mesleki } \\
\text { Deneyim Yil1 }\end{array}$ \\
\hline R1 & Kadın & $\begin{array}{c}\text { Psikolojik Danışma ve } \\
\text { Rehberlik }\end{array}$ & Lisans & 25 \\
\hline $\mathrm{R} 2$ & Kadın & $\begin{array}{c}\text { Psikolojik Danışma ve } \\
\text { Rehberlik }\end{array}$ & Lisans & 19 \\
\hline R3 & Kadın & $\begin{array}{l}\text { Psikolojik Danışma ve } \\
\text { Rehberlik }\end{array}$ & Lisans & 14 \\
\hline MY1 & Kadın & Matematik & Lisans & 25 \\
\hline MY2 & Erkek & Ticaret & Doktora & 33 \\
\hline MY3 & Kadın & İngilizce & Yüksek Lisans & 30 \\
\hline MY4 & Erkek & Ticaret & Lisans & 32 \\
\hline MY5 & Kadın & Kimya & Lisans & 32 \\
\hline MY6 & Kadın & Felsefe & Lisans & 29 \\
\hline
\end{tabular}

Araştırmaya katılan rehber öğretmenlerin ve müdür yardımcılarının özelliklerini incelediğimizde 7'sinin kadın, 2'sinin erkek; 7'sinin lisans, 1'nin yüksek lisans, 1 'nin doktora; en az 14, en çok 33 hizmet yılına sahip oldukları görülmektedir.

Verileri Toplama Aracı ve Geliştirilme Süreci

Araştırmada, veri toplamak amacıyla araştırmacılar tarafından yarı yapılandırılmış bir görüşme formu hazırlanmıştır. Görüşme formunda 6 adet soru bulunmaktadır. Sorular, rehber öğretmenlerin ve müdür yardımcılarının farklı ülkelerden gelen ve anadili Türkçe olmayan yabancı uyruklu öğrencilerin okul ortamında karşılaştıkları problemleri ve öğretmenlerin çözüm önerilerini belirlemeye yönelik olarak hazırlanmıştır. Soruların yer aldığı görüşme formu, KKTC Milli Eğitim ve Kültür Bakanlığı izini alınarak uygulanmıştır.

Yarı yapılandırılmış görüşme formunun soruları, alan-yazından elde edilen bilgiler doğrultusunda araştırmacılar tarafından hazırlanmıştır. Hazırlanmış olan yarı yapılandırılmış görüşme sorularının uygulamasına geçilmeden önce sorular; açıklık, anlaşılırlık ve içerik bakımından, eğitim bilimlerinden iki uzman tarafından incelenmiştir. Uzmanların eleştiri ve önerileri doğrultusunda görüşme sorularına son hali verilmiştir. Daha sonra, soruların işlerliğini değerlendirmek amacıyla iki öğretmenle pilot uygulama yapılmıştır. 
Pilot uygulama sonuçları, görüşme sorularını; açıklık ve katılımcıların sorulara verdikleri cevapların tutarlılığını ölçmek açısından araştırmacılar tarafından incelenmiştir. Böylece soruların, her katılımcı tarafından aynı şekilde anlaşılıp anlaşılmadığı değerlendirilmiştir. Bu çalışmanın sonunda, soruların verileri sağladığı kanısına varılarak, çalışma grubu kapsamında yer alan rehber öğretmenlere ve müdür yardımcılarına uygulanmıştır. Görüşme soruları Ek 1'de yer almaktadir.

\section{Verilerin toplanması ve analizi}

Verilerin toplanması amacıyla öncelikle gönüllülük ve etik kurallar esas alınarak ilgili öğretmenlerden izin alınmıştır. Araştırmaya katılmayı kabul eden rehber öğretmenler ve müdür yardımcıları ile görüşme yeri ve zamanı belirlendikten sonra yüz yüze görüşmeler gerçekleştirilmiştir. Katılımcılarla araştırmacılar tarafından bire bir yapılan görüşmeler başlamadan önce Bilgilendirilmiş Onay Formu okutulup imzalatılmıştır.

Görüşmeler 21.03.2018 ile 05.04.2018 tarihleri arasında katılımcı öğretmenlerin görev yaptıkları okulda gerçekleşmiştir. Görüşmeler ortalama olarak 30-40 dakikalık süreçlerde tamamlanmıştır. Katılımcıların konuşmaları, izin alınarak görüşme esnasında yazılı olarak kayıt edilmiştir. Sesli kayıt yapılmamıştır.

Verilerin analizinde, betimsel analiz ve içerik analizi kullanılmıştır. Betimsel analizin amacı, araştırmacılar tarafından toplanan verilerin, araştırma problemlerine ilişkin olarak neleri söylediğini ön plana çıkarmaktır. İçerik analizi ise sorunların nedenlerine ve çözüm önerilerine ulaşmak amacıyla yapılmıştır. Görüşme kayıtları detaylı şekilde incelenerek yapılan tüm görüşmeler yazılı hale getirilmiştir. Daha sonra rehber öğretmenlerin ve müdür yardımcılarının cevapları incelenerek tablo haline dönüştürülmüştür. Çalışma grubunda yer alan her bir rehber öğretmene ve müdür yardımcısına bir kod (R1, R2, MY1, MY2, vb.) verilmiştir.

\section{Bulgular ve yorumlar}

Bu bölümde, görüşme yapılan katılımcıların sorulara verdikleri cevaplardan elde edilen bulgu ve yorumlara yer verilmiştir. Araştırmanın temel amacı doğrultusunda oluşturulan kategoriler, katılımcıların sorulara verdikleri cevaplardan yapılan alıntılarla desteklenerek sunulmuştur. Görüşmelerden elde edilen verilere uygulanan içerik analizi sonucunda toplam beş kategori belirlenmiştir. Bu kategoriler şunlardır: dil farklılığından dolayı yaşanan sorunlar, kültürel farklılıktan kaynaklı yaşanan sorunlar, okul ortamında yaşanan sorunlar, yabancı uyruklu öğrencilere yönelik oryantasyon çalışmaları ve sorunlara yönelik çözüm önerileri.

1. Dil Farklılı̆̆ından Dolayı Yabancı Uyruklu Öğrencilerin Yaşadıkları Problemler ile İlgili Rehber Öğretmen ve Müdür Yardımcılarının Görüşleri 
Katılımcı rehber öğretmenler ve müdür yardımcıları ile yapılan görüşmelerde, ilk olarak yabancı uyruklu öğrencilerin dil farklılığından dolayı sorun yaşayıp yaşamadıkları sorulmuş ve yaşadıkları sorunları belirtmeleri istemişlerdir. Dil sorunu kategorisine bakıldığında, Kendini Ifade Etmede Zorlanma, Dersleri Takip Etmede Zorlanma ve Türkçe ve Türkçe Dilinde Verilen Derslerde Zorlanma alt temalarından oluştuğu görülmektedir. Tablo 2, yabancı uyruklu öğrencilerin dilden dolayı yaşadıkları sorunlara yönelik rehber öğretmen ve müdür yardımcılarının görüşlerini özetlemektedir:

Tablo 2. Yabancı uyruklu öğrencilerin dilden dolayı yaşadıkları problemler

\begin{tabular}{lccc}
\hline Kat1lımc1 Kodu & $\begin{array}{c}\text { Kendini İfade Etmede } \\
\text { Zorlanma }\end{array}$ & $\begin{array}{c}\text { Dersleri Takip Etmede } \\
\text { Zorlanma }\end{array}$ & $\begin{array}{c}\text { Türkçe ve Türkçe Dilinde } \\
\text { Verilen Diğgr Derslerde } \\
\text { Zorlanma }\end{array}$ \\
\hline R1 & $\sqrt{ }$ & $\sqrt{ }$ & \\
R2 & $\sqrt{ }$ & $\sqrt{ }$ & \\
R3 & & $\sqrt{ }$ & $\sqrt{ }$ \\
MY1 & & $\sqrt{ }$ \\
MY2 & $\sqrt{ }$ & $\sqrt{ }$ & $\sqrt{ }$ \\
MY3 & $\sqrt{ }$ & $\sqrt{ }$ & \\
MY4 & $\sqrt{ }$ & $\sqrt{ }$ & \\
MY5 & $\sqrt{ }$ & & \\
MY6 & & & \\
\hline
\end{tabular}

Tablo 2 incelediğinde, rehber öğretmelerin yabancı uyruklu öğrencilerin Türkçe dilini etkin konuşmadıklarından ötürü kendilerini ifade etmede ve dersleri takip etmede zorlandıklarını belirttikleri görülmektedir. Müdür yardımcıları ise yabancı uyruklu öğrencilerin özellikle Türkçe ve Türkçe dilinde verilen (Türk Dili ve Edebiyatı, Tarih, Coğrafya vb.) dersleri takip etmekte zorlandıklarını belirtmişlerdir. Rehber öğretmenlerden biri bu alt temaya ait olmayan bir görüş bildirmiş ve dil ilgili herhangi bir problem gözlemediğini, öğrencilerle İngilizce dilinde iletişim kurduğunu belirtmiştir. Bu konuda R1, MY1 ve MY6 gözlemledikleri sorunları şöyle ifade etmiştir:

"Yurtdışından gelen dil farklılı̆̆ından dolayı kendilerini ifade etmede ve dersleri anlama konusunda bir takım problemler yaşayabilmektedirler. "(RI)

"Dil farklılı̆̆ından dolayı yaşanan sorunlar ilk anda olabiliyor. Örneğin öğretmenin Türkçe dilinde anlattı̆̆ tarih dersini çocuk o dili bilmediği için anlayamaz. Tabi bu durum sadece tarih dersi için değil diğer bazı Türkçe dersler içinde geçerlidir. Öğretmenin anlattıklarını anlayamadı̆̆ı için arkadaşlarıyla da çok fazla paylaşımda bulunmamak gibi sorunlar yaşayabiliyor.” (MY1)

"Yurtdışından gelen öğrenciler dil farklılı̆̆ından dolayı kendilerini ifade etmede ve dersleri anlama konusunda bir takım problemler yaşamaktadırlar. "(MY6) 
MY3 öğrencilerin Türkçe diline hâkim olamadıkları için kendilerini sözel olarak iyi ifade edememelerinin öğretmenleri ile sorun yaşamalarına sebep olduğunu şu şekilde açıklamıştır:

“Öğrenciler dilden dolayı kendilerini sözel olarak rahat ifade edemiyor. Kullandıkları kelimeler bazen ögretmenler tarafindan saygısızlık olarak algılanıyor. Dil sorunu akademik başarılarını etkiliyor." (MY3)

Rehber öğretmenlerin ve müdür yardımcılarının ifadelerinden yabancı uyruklu öğrencilerin Türkçe diline hâkim olmadıklarından Türkçe dilinde kendini ifade etmede ve dersleri takip etmede sorun yaşadıkları, ayrıca özellikle Türkçe dilinde verilen derslerde öğretimden koptukları anlaşılmaktadır. Alanyazında pek çok çalışmada (Galloway ve Jankins, 2005; Nasrin, 2001; Alyılmaz, Biçer, Çoban, 2015; Sarıkaya, 2014; Polat, 2012; İmamoğlu ve Çalışkan, 2017) bu durum benzer şekilde ortaya konulmaktadır. Karaoğlu (2007) göre göç etmiş bireyler, dili yeterince kullanamadıkları takdirde uyum sorunları yanında psikolojik olarak da kendini yeterince ifade edememekten kaynaklı olarak sosyal davranışları sırasında da sorun yaşayabilmektedir.

2. Kültür Farklılı̆̆ından Dolayı Yabancı Uyruklu Öğrencilerin Yaşadıkları Problemler ile İlgili Rehber Öğretmen ve Müdür Yardımcılarının Görüşleri

Katılımcı rehber öğretmenler ve müdür yardımcıları ile yapılan görüşmelerde, yabancı uyruklu öğrencilerin kültür farklılığından dolayı gözlemledikleri sorunlar sorulmuş ve görüşlerini belirtmeleri istenmiştir. Kültürel Farklılıklar kategorisinin Uyum Sorunu ve Arkadaşlık Kuramama/Yalnızlık Çekme alt temalarından oluştuğu görülmektedir. Tablo 3 yabancı uyruklu öğrencilerin kültür farklılığından dolayı yaşadıkları problemler ile ilgili rehber öğretmenlerin ve müdür yardımcılarının görüşlerini özetlemektedir:

Tablo 3. Yabancı uyruklu öğrencilerin kültürel farklılıktan dolayı yaşadıkları problemler

\begin{tabular}{|c|c|c|c|c|c|c|}
\hline $\begin{array}{c}\text { Katılımc1 } \\
\text { Kodu }\end{array}$ & $\begin{array}{l}\text { Yeme-İ̧̧eme } \\
\text { Alışkanlıkları }\end{array}$ & $\begin{array}{l}\text { Giyim- } \\
\text { Kuşam } \\
\text { Tarzları }\end{array}$ & Dini İnançlar & $\begin{array}{c}\text { Farklı } \\
\text { Tavır, } \\
\text { Davranış ve } \\
\text { Değer } \\
\text { Yargıları }\end{array}$ & $\begin{array}{c}\text { Okul } \\
\text { Kurallarını } \\
\text { Kabul } \\
\text { Etmemekten } \\
\text { Kaynaklı } \\
\text { Uyum } \\
\text { Sorunları }\end{array}$ & $\begin{array}{c}\text { Arkadaşlık } \\
\text { Kurmada } \\
\text { Sorun } \\
\text { Yaşama ve } \\
\text { Yalnızlık } \\
\text { Çekme }\end{array}$ \\
\hline $\mathrm{R} 1$ & $\sqrt{ }$ & $\sqrt{ }$ & $\sqrt{ }$ & $\sqrt{ }$ & & \\
\hline $\mathrm{R} 2$ & $\sqrt{ }$ & $\sqrt{ }$ & & & & \\
\hline R3 & & & & & $\sqrt{ }$ & $\sqrt{ }$ \\
\hline MY1 & & & & & $\sqrt{ }$ & \\
\hline MY2 & & & & & & \\
\hline MY3 & & & & & & $\sqrt{ }$ \\
\hline MY4 & & & & & $\sqrt{ }$ & \\
\hline MY5 & & & & & $\sqrt{ }$ & $\sqrt{ }$ \\
\hline MY6 & $\sqrt{ }$ & $\sqrt{ }$ & $\sqrt{ }$ & $\sqrt{ }$ & $\sqrt{ }$ & $\sqrt{ }$ \\
\hline
\end{tabular}


Tablo 3 incelediğinde, bir rehber öğretmen ve bir müdür yardımcısının kültür farklılığından dolayı yabancı uyruklu öğrencilerin yeme-içme, giyim kuşam tarzlarının, dini inançlarının ve tavır-davranışları ile değer yargılarının oldukça farklı olduğunu ve bu durumun okul ortamında sorunlara neden olduğunu belirtikleri görülmektedir. Kültür farklılığından kaynaklı sorunları R3 ve MY6 şöyle ifade etmiştir:

“Bazı öğrencilerin öğretmene duydukları saygıyı yeterince gösteremediklerini fark ettim. Örneğin öğretmenin yanında yüksek sesle konuşmak veya izin almadan konuşmak gibi." (R3)

“Bilindiği gibi, tüm kurallar ve kanunlar oluşturulurken dikkate alınan kriter o ülkedeki örf ve adetlerdir. Yurtdışından gelen ögrencilerin örf ve adetleri bizim örf ve adetlerimizden ve kurallarımızdan daha farklı olduğundan ilk başta bu ögrenciler bu kuralları benimseyene kadar sorgulamakta, bu sorgulama sürecinde de bir takım problemler yaşanmaktadır. Yeme içme, giyim kuşam, dini inançlar, tavır, davranış ve değer yargılarında olan farklılıklar sebebiyle problemler yaşanmaktadır. "(MY6)

Katılımcı rehber öğretmenler ve müdür yardımcıları, yabancı uyruklu öğrencilerin kültür farklılığından dolayı eğitim sistemini ve okulda uygulanan kuralları kabul etmekte zorlandıkları belirmişlerdir. $\mathrm{Bu}$ durumun uyum sorunlarına yol açtığını belirtmişlerdir. Bu konuda MY5 görüşlerini şu şekilde ifade etmektedir:

"Yurtdışından gelen ögrenciler kurallara uymamayı tercih etmekte ve bunu önceden yaşadıkları ülkeye mal etmeye çalışmaktadırlar. Bazıları disiplin cezalarına kadar vardirlyor." (MY5)

Yine kültürel farklılıktan kaynaklı olarak, katılımcılar, yabancı uyruklu öğrencilerin arkadaşları ile gerçek bir yakınlık kurmakta zorlandıklarını ve yalnızlık problemi yaşadıklarını belirtmişlerdir. MY1 bu durumu şu şekilde açıklamıştır:

"Kültür farklılığından dolayı, arkadaşları ile gerçek bir iletişim kurmada sorunlar yaşlyorlar. Farklı kültürle eğitim, ögrretim almış bir çocuk adapte olana kadar problem yaşlyor." (R3)

Katılımcıların görüşlerinden yola çıkarak, farklı bir kültüre girildiğinde öğrencilerde yalnızlık, uyum sorunu ve içine kapanma gibi durumlar görülebilir. Araştırmanın bu sonuçları alanyazındaki bazı araştırmaların sonuçları ile desteklenmektedir (Polat,2012; Duygu, 2016) . $\mathrm{Bu}$ durumda, aile ve okulun, öğrencilerin hem okula hem de topluma uyum sürecini hızlandırmada işbirliği içinde olmaları büyük önemlidir.

3. Göçle Gelen Yabancı Uyruklu Öğrencilerin Okul Ortamında Yaşadıkları Sorunlar

Katılımcı öğretmenler ile yapılan görüşmelerde, yabancı uyruklu öğrencilerin okul ortamında yaşadıkları problemlere yönelik neler gözledikleri sorulmuştur. Okul ortamında 
yaşanan problemler kategorisinin Illetişim Sorunları, Dersleri Takip Etmeme ve Okul/Sınıf Kurallarına Uymama ve Uyum Sorunları alt temalarından oluştuğu görülmektedir. Tablo 4 yabancı uyruklu öğrencilerin yaşadıkları problemler ile ilgili öğretmen görüşleri özetlemektedir:

Tablo 4. Yabancı uyruklu öğrencilerin okul ortamında yaşadıkları problemler

\begin{tabular}{lccccc}
\hline $\begin{array}{c}\text { Kat1lımc1 } \\
\text { Kodu }\end{array}$ & $\begin{array}{c}\text { Akademik } \\
\text { Başarısızlık }\end{array}$ & $\begin{array}{c}\text { Öğretmenlerle } \\
\text { Iletişimde Sorun } \\
\text { (Çatışma, } \\
\text { Kuralların Ağır } \\
\text { Gelmesi, vb.) }\end{array}$ & $\begin{array}{c}\text { Dersleri } \\
\text { Takip } \\
\text { Etmeme ve } \\
\text { Okul/Snıf } \\
\text { Kurallarına } \\
\text { Uymama }\end{array}$ & $\begin{array}{c}\text { Uyum } \\
\text { Sorunları }\end{array}$ & $\begin{array}{c}\text { Arkadaş Gruplarında } \\
\text { Kabul } \\
\text { Görmeme/Dışlanma }\end{array}$ \\
\hline R1 & & $\sqrt{ }$ & $\sqrt{ }$ & \\
R2 & $\sqrt{ }$ & $\sqrt{ }$ & $\sqrt{ }$ & $\sqrt{ }$ \\
R3 & $\sqrt{ }$ & $\sqrt{ }$ & $\sqrt{ }$ & \\
MY1 & $\sqrt{ }$ & $\sqrt{ }$ & $\sqrt{ }$ & $\sqrt{ }$ \\
MY2 & $\sqrt{ }$ & $\sqrt{ }$ & $\sqrt{ }$ & $\sqrt{ }$ & \\
MY3 & $\sqrt{ }$ & $\sqrt{ }$ & $\sqrt{ }$ & $\sqrt{ }$ \\
MY4 & & & & \\
MY5 & & & & \\
MY6 & & & & & \\
\hline
\end{tabular}

Tablo 4 incelediğinde, rehber öğretmenlerin ve müdür yardımcılarının, yabancı uyruklu öğrencilerin en çok dersleri takip etmede ve okul kurallarına uyma da sorun yaşadıklarını ve genel olarak bu öğrencilerin okula uyumunun uzun zaman aldığını belirtmişlerdir. Katılımcı öğretmenler, uyum sorunlarından dolayı öğrencilerin arkadaş ortamlarına katılmadığı ve sorun yaşadıklarını belirtmişlerdir. Bu konuda R3 ve MY2 gözlemledikleri sorunları şöyle ifade etmişlerdir:

"Yabancı uyruklu ögrenciler derslerin geldikleri okullardan çok farklı ve zor olduğunu ifade ediyorlar. Başarı oranı yüksek olan sınıflarda okuyanlar genellikle arkadaşları tarafindan dişlanıyor." (R3)

"Geldikleri çevre ve okul kuralları farklı olması ve geldikleri okulun kurallarına adapte olana kadar okul idaresi ve ögrretmenleriyle çatışma yaşarlar. Her ögretmenin kendi dersine yönelik farklı kuralları olabilir. Çocuklar farklı kültürden, farklı kurallardan gelmiştir. Öğretmenlerine karşı saygısızlık ve okul disiplin kurallarına aykırı davranışlarla karşılaşılabiliyoruz." (MY2) 
Rehber öğretmen ve müdür yardımcılarının ifadelerinden, yabancı uyruklu öğrencilerin okul ortamında yaşadıkları problemlerin dersleri takip etmede, okul ve sınıf kurallarına uyma konusunda olduğu anlaşılmaktadır. Bu sorunlar beraberinde farklı sorunlar getirmekte, öğretimden kopan öğrenci, öğretmenleri ile çatışmaya girmekte ve arkadaş gruplarından dışlanmaktadır. Ayrıca sınıf ortamında disiplinsiz davranışlarda bulunarak, sınıf düzenini bozmaktadırlar. Alan-yazına göre, sınıf içerisinde istenmeyen davranışlar farklı şekillerde ortaya çıkabilmektedir (Korkmaz, 2005; Çelik, 2002; Çetin, 2013). Bunlar; gerçekleştirilen davranışın, a) öğrencinin hem kendisinin hem de arkadaşlarının öğrenmesine engel olması, b) hem kendisinin hem de arkadaşlarının güvenliğini tehlikeye atması, c) okulun veya arkadaşlarının araç-gereçlerine zarar vermesi; d) öğrencinin diğer öğrencilerle kaynaşmasını engellemesi şeklinde olabilmektedir. Rehber öğretmenlerin ve müdür yardımcılarının ifadelerinden, yabancı uyruklu öğrencilerin davranışlarının hem kendisinin hem de arkadaşlarının öğrenmelerini ve sosyalleşmesini engelleyecek şekilde ortaya çıktığı anlaşılmaktadır. Can güvenliğini tehlikeye atma veya okul eşyalarına zarar verme boyutlarında rehber öğretmen ve müdür yardımcılarının ifadelerine rastlanmamıştır. Güngör (2015) ve Polat (2012) çalışmalarında da bu araştırmanın bulguları ile benzer şeklide disiplin problemleri bulgularına rastlamışlardır.

Oryantasyona Yönelik Olarak Yapılan Çalışmalar ile İlgili Rehber Öğretmen ve Müdür Yardımcılarının Görüşleri

Katılımcı rehber öğretmen ve müdür yardımcıları ile yapılan görüşmelerde, yabancı uyruklu öğrencilerin okula uyumlarını kolaylaştırmak adına bir oryantasyon programı uygulayıp uygulamadıkları sorulmuş ve ne gibi çalışmalar yaptıklarını belirtmeleri istenmiştir. Oryantasyon kategorisinin Okulu ve Ĕgitim Sistemini Tanıtma, Öğrenci-Aile Görüssmeleri, Türkçe Diline Yönelik Çalışmalar ve Diğer Öğrenci ve Öğretmenlerden Yardım Alma alt temalarından oluştuğu görülmektedir. Tablo 5, yabancı uyruklu öğrencilerin oryantasyonuna yönelik olarak ne gibi çalışmalar yapıldığını özetlemektedir:

Tablo 5. Yabancı uyruklu öğrencilere yönelik oryantasyon çalışmaları.

\begin{tabular}{|c|c|c|c|c|c|c|c|}
\hline $\begin{array}{c}\text { Katılımc1 } \\
\text { Kodu }\end{array}$ & $\begin{array}{c}\text { Okulun } \\
\text { Kendilerinden } \\
\text { Beklentilerini } \\
\text { Ortaya Koyma }\end{array}$ & $\begin{array}{l}\text { Okulun } \\
\text { Fiziki } \\
\text { Çevresini } \\
\text { Tanıtma }\end{array}$ & $\begin{array}{c}\text { Sınıf } \\
\text { Ortamında } \\
\text { Yapılan } \\
\text { Farkındalık } \\
\text { Calıșmaları }\end{array}$ & $\begin{array}{l}\text { Öğrenci } \\
\text { ve Aile } \\
\text { İle } \\
\text { Görüşme }\end{array}$ & $\begin{array}{c}\text { Yurtdışından } \\
\text { Gelmiş Diğer } \\
\text { Öğrenciler } \\
\text { İle } \\
\text { Tanıştırma }\end{array}$ & $\begin{array}{c}\text { Türkçe } \\
\text { Diline } \\
\text { Yönelik } \\
\text { Çalışmalar }\end{array}$ & $\begin{array}{l}\text { Ögrretmenlerden } \\
\text { Yardım İsteme }\end{array}$ \\
\hline R1 & $\sqrt{ }$ & $\sqrt{ }$ & & & & & \\
\hline $\mathrm{R} 2$ & & & $\sqrt{ }$ & $\sqrt{ }$ & & & \\
\hline R3 & $\sqrt{ }$ & $\sqrt{ }$ & & & & & \\
\hline MY1 & & & & & & $\sqrt{ }$ & \\
\hline MY2 & & & & $\sqrt{ }$ & $\sqrt{ }$ & $\sqrt{ }$ & $\sqrt{ }$ \\
\hline MY3 & & & & & & $\sqrt{ }$ & $\sqrt{ }$ \\
\hline
\end{tabular}




\begin{tabular}{lccc}
\hline MY4 & $\sqrt{ }$ & $\sqrt{ }$ & \\
MY5 & $\sqrt{ }$ & $\sqrt{ }$ & $\sqrt{ }$ \\
MY6 & $\sqrt{ }$ & $\sqrt{ }$ & $\sqrt{ }$ \\
\hline
\end{tabular}

Tablo 5 incelediğinde, rehber öğretmenlerin oryantasyona yönelik olarak öğrencilere genel olarak eğitim sistemini tanıttıkları, kendilerinden neler beklendiğini açıkladıkları ve okulun fiziksel çevresini tanıttıklarını belirtmişlerdir. Ayrıca rehber öğretmenlerden biri sınıf ortamında farklılıkları kabul etmeye yönelik bir takım farkındalık çalışmaları yaptığını belirtmiştir:

"Sınıf arkadaşları ile görüşme, farklıları kabul etme ve iletişim becerileri gibi konuları sınıfla konuşarak farkındalıklarını artırmaya çalışıyorum. Yeni gelen öğrenci ve ailesi ile mutlaka görüşüyorum. "(R2)

Görüşülen müdür yardımcıları ise Türkçe dilini öğrenmelerine yönelik çalışmalar yaparak öncelikle dil sorununu gidermeye çalıştıklarını belirtmişlerdir. Aynı zamanda okula daha önce kayıt olmuş yabancı uyruklu öğrencilerden ile tanıştırarak arkadaşlık kurmalarını sağladıklarını belirtmişlerdir. Bu konuda MY2 yaptığı çalışmaları şöyle ifade etmiştir:

“Oryantasyon sürecinde dil öğrenmeye ve uyuma yönelik bazı çalışmalar oluyor. Dil sorunu verilen kurslarla giderilmekte, uyum sorunu ise sınıf içerisinde arkadaşları özellikle de yine başka bir ülkeden daha önce okulumuza kaydolmuş olan öğrenciler ile arkadaşlık kurması sağlanarak aşıllyor. Öğretmenlerin yardımını alıyoruz. ”(MY2)

Katılımcıların ifadelerinden yabancı öğrencilerin oryantasyon çalışmalarına yönelik olarak öğrenci ve veli görüşmeleri yaptıkları, okulun hem fiziki hem de sistemi ile ilgili bilgilendirme yaptıkları, Türkçe dilini öğrenmeye yönelik kurslar açtıklarını ve diğer yabancı uyruklu öğrenciler ile kaynaştırma çalışmaları yaptıkları görülmektedir. Özellikle rehber öğretmenlerin ifadelerinden öğrencilere yönelik bireysel bir program uygulamadıkları anlaşılmaktadır. Rehber öğretmenler, genel çerçevede, çocuk ve ailesi ile görüşüp, bilgilendirme düzeyinde bir iletişim kurmaktadırlar. Öğrenciye göre bireysel programlar hazırlanması, programın çocuğun gereksinimleri ve şartlarına göre şekillenecek olmasından daha etkili olacağı düşüncesi ile önerilmektedir.

\section{Yabancı Uyruklu Öğrencilerin Yaşadıkları Problemlere Yönelik Çözüm Önerileri}

Katılımcı rehber öğretmen ve müdür yardımcıları ile yapılan görüşmelerde, yabancı uyruklu öğrencilerin problemlerine yönelik olarak ne gibi çalışmalar önerdikleri sorulmuştur. Çözüm önerileri temasının İşbirliği, Kaynaştırma Etkinlikleri ve Zorunlu Türkçe Kursları alt temalarından oluştuğu görülmektedir. Tablo 6 yabancı uyruklu öğrencilerin problemlerinin çözümüne yönelik öğretmenlerin önerilerini özetlemektedir: 
Tablo 6. Yabancı uyruklu öğrencilerin sorunlarının çözümüne yönelik öneriler

\begin{tabular}{|c|c|c|c|c|c|c|}
\hline $\begin{array}{c}\text { Katılıme1 } \\
\text { Kodu }\end{array}$ & $\begin{array}{c}\text { Maddi } \\
\text { Durumu } \\
\text { Uygun } \\
\text { Olmayanlara } \\
\text { Destek }\end{array}$ & $\begin{array}{c}\text { İşbirlikçi } \\
\text { Çalışmalar } \\
\text { (Okul } \\
\text { İdaresi, } \\
\text { Öğgrenci, } \\
\text { Öğretmen, } \\
\text { Rehber } \\
\text { Öğretmen } \\
\text { ve Veli) } \\
\end{array}$ & $\begin{array}{c}\text { Sosyal } \\
\text { Aktiviteler İle } \\
\text { Kaynaştırma } \\
\text { Çalış̧maları }\end{array}$ & $\begin{array}{c}\text { Zorunlu } \\
\text { Türkçe } \\
\text { Kursları }\end{array}$ & $\begin{array}{l}\text { Farklılıklar } \\
\text { Kabul Etme } \\
\text { Çalışmaları }\end{array}$ & $\begin{array}{l}\text { Öğgrencilere ve } \\
\text { Ögrretmenlere } \\
\text { Eğitim Verme }\end{array}$ \\
\hline R1 & $\sqrt{ }$ & $\sqrt{ }$ & & & & \\
\hline $\mathrm{R} 2$ & $\sqrt{ }$ & $\sqrt{ }$ & $\sqrt{ }$ & & & \\
\hline R3 & & $\sqrt{ }$ & & $\sqrt{ }$ & $\sqrt{ }$ & $\sqrt{ }$ \\
\hline MY1 & & $\sqrt{ }$ & & $\sqrt{ }$ & & \\
\hline MY2 & & $\sqrt{ }$ & & $\sqrt{ }$ & & $\sqrt{ }$ \\
\hline MY3 & & $\sqrt{ }$ & & $\sqrt{ }$ & & \\
\hline MY4 & & $\sqrt{ }$ & $\sqrt{ }$ & $\sqrt{ }$ & & $\sqrt{ }$ \\
\hline MY5 & & $\sqrt{ }$ & $\sqrt{ }$ & $\sqrt{ }$ & & $\sqrt{ }$ \\
\hline MY6 & & $\sqrt{ }$ & $\sqrt{ }$ & $\sqrt{ }$ & & $\sqrt{ }$ \\
\hline
\end{tabular}

Tablo 6 incelediğinde, görüşülen rehber öğretmenler, maddi durumu uygun olmayan öğrenciler için destek sağlamanın (Kıyafet sağlama, kurs düzenleme, kitapların alınması, vb.) önemine değinmişlerdir. Ayrıca, uzun vadeli Türkçe kurslarından yararlanmalarının da sorunların çözümüne yönelik olarak katkı sağlayıcı olduğunu belirtmişlerdir. Ekonomik ve sosyal uyum için sosyal hizmetlerin takibinde olmaları gerektiği de vurgulanmıştır.

Görüşülen müdür yardımcıları yabancı uyruklu öğrencilerin yaşadıkları sorunların çözümünde rehber öğretmenleri kilit bir rolde görmektedir. MY3 bu durumu şu şekilde ifade etmişlerdir:

"Yabancı uyruklu öğrencilerin okula kolay adapte olmaları için okulla ilgili detaylı bilgi verilmelidir. Rehber ögretmenler bu öğrenciler ve velileri ile sürekli iletişim içerisinde olmalıdır."(MY3)

Hem rehber öğretmenler hem de müdür yardımcıları okulda bulunan paydaşların işbirliği içerisinde çalışmasının önemine değinmişlerdir.

\section{Sonuçlar ve öneriler}


Araştırma sonucunda, rehber öğretmenlerin ve müdür yardımcılarının eğitim-öğretim sürecinde yabancı uyruklu öğrencilerle ilgili bazı sorunlar gözlemledikleri ortaya konulmuştur. $\mathrm{Bu}$ sorunların en başında dil, kültür farklılığı, dersle ilgilenmeme/öğretimden kopma ve uyum problemleridir. Bu sorunların her biri birbiri ile bağlantılı olarak birbirinin sebebi ve sonucu olabilmektedir. Rehber öğretmenlerin ve müdür yardımcılarının ifadelerinden, yabancı uyruklu öğrencilerin Türkçe diline hâkim olmamalarından, Türkçe dilinde kendini ifade etmede ve arkadaş ilişkilerinde sorun yaşadıkları, ayrıca Türkçe dilinde verilen derslerde öğretimden koptukları anlaşılmaktadır. Kültür farklılığından dolayı yabancı uyruklu öğrencilerin tavır, davranış ve değer yargılarında oldukça büyük farklıklar vardır. Bu durum yabancı uyruklu öğrencilerin okula uyumunu zorlaştırmakta, eğitim sistemini ve okulda uygulanan kuralları kabul etmelerini zorlaştırmaktadır. Bu durumda, aile ve okulun, öğrencilerin okula ve topluma uyum sürecini hızlandırmada işbirliği içinde olmaları büyük önem taşımaktadır. Öğrencinin zamanın büyük bir kısmını okul ortamında geçirdiği düşünüldüğünde okula çok büyük sorumluluklar düştüğü aşikardır. Öğrencilerin durumlarını yerinde görmek, kültürlerini tanımaya çalışmak, aile yapısını öğrenmek ve yabancı uyruklu öğrencilerin yerli öğrencilerle kaynaşmasını sağlamak için çeşitli etkinliklerin yapılması kültürle ilgili sorunların çözümünde etkili olabilir. Katılımcıların ifadelerinden yabancı öğrencilerin oryantasyon çalışmalarına yönelik olarak öğrenci ve veli görüşmeleri yaptıkları, okulun hem fiziki hem de sistemi ile ilgili bilgilendirme yaptıkları, Türkçe dilini öğrenmeye yönelik kurslar açtıklarını ve diğer yabancı uyruklu öğrenciler ile kaynaştırma çalışmaları yaptıkları görülmektedir. Özellikle rehber öğretmenlerin ifadelerinden öğrencilere yönelik bireysel bir program uygulamadıkları anlaşılmaktadır. Rehber öğretmenler, genel çerçevede, çocuk ve ailesi ile görüşüp, bilgilendirme düzeyinde bir iletişim kurmaktadırlar. Öğrenciye göre bireysel programlar hazırlanması, programın çocuğun gereksinimleri ve şartlarına göre şekillenecek olmasından daha etkili olacağı düşüncesi ile önerilmektedir. Rehber öğretmen ve müdür yardımcılarının ifadelerinden, yabancı uyruklu öğrencilerin okul ortamında yaşadıkları problemlerin dersleri takip etmede, okul ve sınıf kurallarına uyma konusunda olduğu anlaşılmaktadır. Bu sorunlar beraberinde farklı sorunlar getirmekte, öğretimden kopan öğrenci, öğretmenleri ile çatışmaya girmekte ve arkadaş gruplarından dışlanmaktadır. Yabancı uyruklu öğrencilerin sorunlarının çözümüne yönelik hem rehber öğretmenler hem de müdür yardımcıları okulun tüm paydaşlarının ve velilerin işbirliği içerisinde çalışmasının önemini vurgulamışlardır. Uzun vadeli verilecek Türkçe kurslarının da önemine değinmişlerdir. Milli Eğitim Bakanlığı tarafindan hazırlanacak kapsamlı bir oryantasyon programı, rehber öğretmenlere detaylı bir uygulama eğitimi verilerek uygulamaya konulması araştırmacılar tarafından önemli 
görülmektedir. Yabancı uyruklu öğrencilerin sağlıklı bir uyum sürecinden geçmeleri için aile tanıma ve iletişim çalışmalarının da oryantasyon programına eklenmesi gerekli görülmektedir. KKTC'nin bulunduğu coğrafyadan ötürü göç almaya devam etmekte ve her geçen gün göç yoluyla gelmiş çocukların sayısında ciddi bir artış olmaktadır. Değişen dünyada yaşam şartları çok kültürlü eğitimi zorunlu kılmaktadır. Bu çerçevede Milli Eğitim Bakanlığı’nın çok kültürlü eğitim ve oryantasyon programı geliştirme çalışmalarına başlaması zorunlu görülmektedir.

İleride gerçekleştirilecek araştırmalar için şu öneriler verilebilir: a) Çalışmanın örneklemi değiştirilerek çalışma tekrar edilebilir. Yabancı uyruklu öğrenciler, velileri ve öğretmenleri ile görüşmeler yapılabilir. b) $\mathrm{Bu}$ araştırmada, yabancı uyruklu öğrencilerin okul ortamında yaşadıkları sorunlar incelenmiştir. Genel olarak problemlerinin inceleneceği çalışmalar gerçekleştirilebilir. c) Yabancı uyruklu öğrencilerin eğitim-öğretim sürecinde yaşadıkları sorunlara ilişkin çeşitli değişkenler (göç ettikleri ülke, göç nedenleri, vb.) içeren nicel araştırmalar yapılabilir.

\section{Kaynaklar}

Akkayan, N, T. (1979), Göç ve Değişme, İstanbul: İstanbul Üniversitesi Edebiyat Fakültesi Yayınları.

Atalay, İ. (1994), Türkiye Coğrafyast, İzmir: Ege Üniversitesi Basımevi.

Atasoy, A. (2011). Kuzey Kıbrıs Türk Cumhuriyeti'nin Nüfus Coğrafyası/Population Geography Of Turkish Republic Of Northern Cyprus.Mustafa Kemal Üniversitesi Sosyal Bilimler Enstitüsü Dergisi, 8(15), 29-62.

Berry, J.W. ve Sam, D.L. (1995), Acculturative stres among young immigrants in Norway. Scandinavian Journal of Psychology, 36

Büyüköztürk, Ş., Çakmak, E. K., Akgün,Ö. E., Karadeniz, Ş., Demirel, F. (2009). Bilimsel Araştırma Yöntemleri. Ankara: Pegem Akademi.

Çağlar, A. (1997). Yeni Bir Göçmen Türü: Türk Üniversitelerinde Yabancı Uyruklu Öğrenci Olmak. II. Ulusal Sosyoloji Kongresi. Toplum ve Göç: 20-21-22 Kasım 1996-Mersin: Bildiri (152-162).Ankara: DİE ve Sosyoloji Derneği Yayını.

Duygu, H. (2016). Alanya Örneğinde Yabancı Uyruklu Ortaokul Öğrencilerinin Karşılaştıkları Sorunlar. (Basılmamış Yüksek Lisans Tezi). Abant İzzet Baysal Üniversitesi Eğitim Bilimleri Enstitüsü İlköğretim Anabilim Dalı Sosyal Bilgiler Öğretmenliği Bilim Dalı, Bolu.

Ekiz, D. (2003). Eğitimde Araştırma Yöntem ve Metotlarına Giriş. Ankara: Anı Yayıncılık. Ekiz, D. (2009). Bilimsel Araştırma Yöntemleri. Ankara: Anı Yayıncılık. 
Gün, Z. (2002), Çocuk ve Göç. (Basılmamış Yüksek Lisans Tezi). Ege Üniversitesi Sosyal Bilimler Enstitüsü, İzmir.

Gün, Z. (2000), Kültürler Arası Gelişimsel Psikoloji, (Yayınlanmamış Yüksek Lisans Tezi). E.Ü. Sosyal Bilimler Enstitüsü, İzmir.

Güngör, F. (2015). Yabancı uyruklu ilkokul öğrencilerinin eğitim-öğretiminde yaşanan sorunlara ilişkin öğretmen ve ögrenci görüşleri. (Yayımlanmamış Yüksek lisans Tezi). Anadolu Üniversitesi Eğitim Bilimleri Enstitüsü, Eskişehir.

Karaoğlu, F. (2007). Yabancı Uyruklu Öğrencilerde Uyma Davranışı: TÖMER Örneği. (Yayımlanmamış Yüksek lisans Tezi). Gazi Üniversitesi, Ankara.

Karataş, Z. (2015). Sosyal Bilimlerde Nitel Araştırma Yöntemleri. Manevi Temelli Sosyal Hizmet Araştırmaları Dergisi, 1(1), 62-80.

Kartal, S. K. (1978). Kentleşme ve Insan. Ankara: TODAİE Yayınları.

Kaştan, Y. (2015). Türkiye'de Göç Yaşamış Çocukların Eğitim Sürecinde Karşılaşılan Problemler, Uluslararası Sosyal ve Eğitim Bilimleri Dergisi. 2/4, 216-229.

Kılıç, E. (2014). Antalya'da Yaşayan Yabancı Uyruklu Aile Çocuklarının Karşılaştı̆̆ı Eğitim Sorunları (Uluslararası Özel Antalya Rus Okulu Örneği). (Yayınlanmamış Yüksek lisans Tezi). Akdeniz Üniversitesi Eğitim Bilimleri Enstitüsü, Antalya.

Keleş, R. (1998). Kent Bilim Terimleri Sözlüğ̈̈. Ankara: İmge Kitabevi

Keser, U. (2006). Kıbrıs' ta Göç Hareketleri ve 1974 Sonrasında Yaşananlar. ÇTTAD, V/12, (2006/Bahar), s. 103-128.

Koçak, Y. ve Terzi, E. (2012). Türkiye'de Göç Olgusu, Göç Edenlerin Kentlere Olan Etkileri ve Çözüm Önerileri, Kafkas Üniversitesi İktisadi ve İdari Bilimler Fakültesi Dergisi, $3 / 3,163-184$.

KKTC Milli Eğitim ve Kültür Bakanlığı, 2017-2018 Eğitim İstatistikleri Yıllığı, http://eohd.mebnet.net/?q=node/34 adresinden 20 Mart 2018 tarihinde erişildi.

Nasrin, F. (2001). International Female Graduate Students' Perceptions of Their Adjustment Experiences and Coping Strategies at an Urban Research University, Speeches/ Meeting Papers. Web: www.eric.com adresinden 5 Mart 2018'de alınmıstır.

Özdemir, S.M, Benzer, H. ve Akbaş, O (2009). "Almanya'da Yaşayan 15-19 Yaş Türk Gençlerinin Eğitim Sorunlarına İlişkin Bir İnceleme (Kuzey Ren Vestfalya Örneği)”, Ahi Evran Üniversitesi Kırşehir Eğitim Fakültesi Dergisi (KEFAD). 10(1): 23-40

Özer, İ. (2004). Kentleşme, Kentlileşme ve Kentsel Değişme. Bursa: Ekin Kitabevi. 
Özerem, A. ve Takır, A. (2018). Yurtdışından Göç Etmiş Yabancı Uyruklu Öğrencilerin Ĕ̆itimsel Sorunlarına Yönelik Öğretmen Görüşleri. CYICER 2018 7. Uluslararası Kıbrıs Eğitim Araştırmaları Konferansı: Bildiriler. 7-9 Haziren 2018: KKTC.

Polat, F. (2012). Türkiye'de Öğrenim Gören Yabancı Uyruklu İlköğretim Öğrencilerinin Karşılaştıkları Sorunlar ve Çözüm Önerileri. (Yayınlanmamış Yüksek lisans Tezi). F1rat Üniversitesi Sosyal Bilimler Enstitüsü, Elazı ̆̆.

Sam D.L. (1991), Acculturation of immigrant: A Psycologcial Survey Among Young Immigrant in Norway. Bergen: Bergen University Press,

Sarıkaya, H.S. (2014). Belçika Flaman Bölgesi Eğitim Sisteminde Türk Kökenli Çocukların Yaşadığ 1 Temel Eğitim Sorunların İncelenmesi, Akademik Sosyal Araştırmalar Dergisi. 8: 246-260.

Şahin, C. (1999). Yurt Dışı Yaşantısı Geçiren ve Geçirmeyen Anadolu Lisesi Öğrencilerinin Sosyal Beceri Düzeyleri. (Yayınlanmamış Doktora Tezi). Ankara: Gazi Üniversitesi.

Sezgin, A. A. ve Yolcu, T. (2016). Göç ile Gelen Uluslararası Öğrencilerin Sosyal Uyum ve Toplumsal Kabul Süreci. Humanitas, 4(7), 419-438.

Tezcan, M. (1997), Eğitim Sosyolojisi, Ankara Üniversitesi Yayınları, Ankara.

Topsakal, C., Merey, Z. ve Keçe, M. (2013). Göçle Gelen Ailelerin Çocuklarının Eğitim Öğrenim Hakkı Ve Sorunları Üzerine Nitel Bir Çalışma. Uluslararası Sosyal Araştırmalar Dergisi. 6 (27): 546-560

Tunç, A. Ş. (2015). Mülteci Davranışı Ve Toplumsal Etkileri: Türkiye‘deki Suriyelilere İlişkin Bir Değerlendirme. TESAM Akademi Dergisi, 2, 29-63.

Uluocak, G.P. (2009). İç Göç Yaşamış Ve Yaşamamış Çocukların Okulda Uyumu, Dokuz Eylül Üniversitesi Buca Ĕ̌̆itim Fakültesi Dergisi. 26: 35-44

Yıldırım ve Şimşek, (2008). Sosyal Bilimlerde Nitel Araştırma Yöntemleri. Ankara: Seçkin Yayıncilik.

Yıldız, Ö. (2013). Türkiye Kamplarında Suriyeli Sığınmacılar: Sorunlar, Beklentiler, Türkiye ve Gelecek Algısı. Sosyoloji Araştırmaları Dergisi, 16(1), 141-169. 


\section{Görüşme Formu}

\section{Arastırmanın Amaci ve Soruları:}

Kuzey Kıbrıs Türk Cumhuriyeti'nde bulunan devlet kolejlerinde öğrenim gören yabancı uyruklu öğrencilerin, okul ortamında karşılaştıkları sorunları öğrenci, öğretmen ve veli gözünden ortaya koymak ve çözüm önerileri geliştirmektir. Bu temel amaç doğrultusunda şu sorulara yanıt aranmaktadır:

1. Öğrenci, öğretmen ve velilere göre KKTC devlet kolejlerinde öğrenim gören yabancı uyruklu öğrencilerin sorunları nelerdir?

2. Yaşanılan sorunların çözümüne yönelik öğretmen ve müdür yardımcılarının görüşleri nelerdir?

\section{Tarih:.../.../2017}

Saat(Başlangıç/Bitiş):.............

\section{Giris}

Merhaba, ben Ayşen Özerem/Aygil Takır.

Sizi Kuzey Kıbrıs Türk Cumhuriyeti'nde bulunan devlet kolejlerinde öğrenim gören yabancı uyruklu öğrencilerin, okul ortamında karşılaştıkları sorunları öğretmen ve müdür yardımcısı gözünden ortaya koymaya ve çözüm önerileri geliştirmeyi amaçlayan bir çalışmanın parçası olmaya davet ediyoruz. $\mathrm{Bu}$ çalışmaya katılımınız tamamıyla gönüllülük esasına dayanmaktadır. Çalışmaya katılımınıza yönelik hiç kimseye bilgi verilmeyecek ve cevaplarınız hiç kimse ile paylaşılmayacaktır. Görüşme yapılan diğer öğrenci, öğretmen ve veliler konuşulanları kesinlikle duymayacak veya okumayacaklardır. Araştırma raporunda isimleriniz kesinlikle kullanılmayacaktır.

Okul ortamında yaşanılan sorunların doğru bir şekilde belirlenebilmesi için görüşmede vereceğiniz samimi cevaplar büyük önem taşımaktadır. Herhangi bir sebepten ötürü cevaplamak istemediğiniz soru varsa cevaplandırmayabilirsiniz. Ancak bu araştırma verdiğiniz tam cevaplarla daha geçerli ve değerli olacaktır. Sonuçlar sadece araştırma amacıyla kullanılacaktır. Bu görüşme formuna cevap vermeyi kabul ederek çalışmaya katılımınıza onay vermiş olmaktasınız. Toplanan veri sadece araştırmacılar tarafından düzenlenecek ve analiz edilecektir.

Katkılarınız için şimdiden teşekkür ederim.

Görüşmeye başlamadan önce sormak istediğiniz herhangi bir soru ya da belirtmek istediğiniz düşünceniz varsa yanitlamak isterim.

Görüşmeye devam etmek istiyor musunuz?

Görüşmenin yaklaş1k olarak 35-40 dakika süreceğini düşünüyorum. İzninizle başlamak istiyorum.

\section{Görüşme Soruları:}

1a. Kaç yaşındasınız?

1b. Eğitim durumunuz nedir? 
1c. Kaç yıllık öğretmensiniz?

1d. Branşınız nedir?

2. Öğrencinizle dil farklılığından dolayı ne gibi sorunlar yaşadıklarını düşünüyorsunuz?

3. Öğrencinizde ne gibi kültür farklılıkları gözlemlediniz? Okul rutinlerine uymada, ders çalışma alışkanlıklarında, görgü, genel davranış kurallarında ne gibi farklılıklar gözlediniz?

4. Öğrenciyi okula alıştırmak için ne gibi oryantasyon programı kullandınız? Bu programda ne gibi etkinlikler yaptınız? Etkinlikler amacına ulaştı mı?

5. Göçle gelen yabancı uyruklu öğrencilerin yaşadıkları sorunlar nelerdir (arkadaşları, dersler, öğretmenler, vb.)? Genel uyum süreci ile ilgili yaşadıkları zorluklar nelerdir?

6. Yabancı uyruklu öğrencilerin sorunlarının çözümüne okulunuzda ne gibi çalışmalar yapıldı? Başka neler yapılabilir?

Eklemek istediğiniz başka düşünceleriniz var mı? Varsa nelerdir?

Zaman ayırdığınız için teşekkür ederim. İyi günler. 